\title{
Reconfiguring Australia's Literary Canon: Antipodean Cultural Tectonics
}

Salhia Ben-Messahel

\section{(2) OpenEdition \\ 1 Journals}

Electronic version

URL: https://journals.openedition.org/ces/7882

DOI: $10.4000 /$ ces.7882

ISSN: 2534-6695

Publisher

SEPC (Société d'études des pays du Commonwealth)

\section{Printed version}

Date of publication: 1 September 2011

Number of pages: $77-91$

ISSN: 2270-0633

\section{Electronic reference}

Salhia Ben-Messahel, "Reconfiguring Australia's Literary Canon: Antipodean Cultural Tectonics", Commonwealth Essays and Studies [Online], 34.1 | 2011, Online since 16 November 2021, connection on 01 December 2021. URL: http://journals.openedition.org/ces/7882 ; DOI: https://doi.org/10.4000/ ces.7882

\section{(c) (i) $\odot$}

Commonwealth Essays and Studies is licensed under a Licence Creative Commons Attribution - Pas d'Utilisation Commerciale - Pas de Modification 4.0 International. 


\section{Reconfiguring Australia's Literary Canon: Antipodean Cultural Tectonics ${ }^{1}$}

This paper shows how an Australian community imagined by the European continent has evolved to become more inclusive of otherness, be it in the form of non-AngloAustralian cultures, Australian regional cultures, or a significant Indigenous culture intimately linked to the land. In this process, which is comparable to tectonic shifts, some Australian authors have attempted, within a $21^{\text {st }}$-century global village, to map intercultural spaces that reveal a pervasive sense of emptiness and the uncanny.

Scientific evidence suggests that before the separation of continents during the ice age, Australia was attached to the southeast Asian landmass, and that the presence of Indigenous peoples owes to their migrations, travelling first through land and then, in the final stage of evolution, by sea. During the passage of time between the coming of the Aborigine more than 50,000 years ago and the settlement of the White man in 1788, the changes in Australia's appearance were caused probably more by changes in climate than by human activity. Even though Australia is often referred to as an ancient land or the oldest of continents, suggesting a sense of stability and legitimacy, it has not always had its present topography or geographic position. Like the other continents, it is on the move, and scientists predict it is aiming for collision with South-East Asia. Geographers have for instance shown that Australia was originally joined to a super-continent, referred to as Pangaea, meaning "all lands" in Greek, before it separated and drifted across the earth's surface, undergoing a variety of different climatic changes and geological manifestations. Thus, in focusing on Australia's journey across the earth, it is possible not only to gain a greater insight into the evolution of the Australian landform, soil, flora and fauna, but also, through analogy, to grasp the significance of the land and its diversity in the Australian consciousness and in the construction of cultural identity.

The development of the settler society, which marked the economic extension of Britishness at the end of the $18^{\text {th }}$ century, collided with the existing nomadic lifestyle of the Indigenous people, mapping Australia as an old but new continent labelled "Terra Nullius," as a space controlled by colonial forces and resting upon a Black/White binary. The white settlers and convicts established a new home along the coast while the centre, which they commonly called the Dead Heart, was Indigenous territory and the nexus of the uncanny, the place of the Dreamtime and of the Rainbow Serpent who came from beneath the ground to design Australia's topography - mountains, ridges - and natural environment. Yet, the emergence of nationalism in the first phase of the $19^{\text {th }}$ century disrupted the political and cultural strata of the colonial society and was instrumental in developing a space for authors who wondered whether Australia was distinct from Britain in the appreciation of place, culture and identity. These questions weigh on the different layers of Australian

1. I would like to thank Tom Thompson and ETT Imprint for permission to use original material from Mudrooroo's Dalwurra in this article. 
society and, during the $20^{\text {th }}$ and $21^{\text {st }}$ centuries, have begun to interact in a process of convergence and subduction.

Writing addresses "Australian identity" through a redefinition of space from three distinct perspectives: the British legacy, cultural nationalism and multiculturalism. So much so that issues about modern Australia's entanglement with its sacred sites and the deterritorialization of cultural heritage in a globalized modernity arise and rock the mainstream. Indeed, as national and ethnic boundaries are breaking down in the multicultural and post-colonial nation, one encounters a paradoxical reinvestment in homeland, territorial integrity, regionalism, localism, ethnocentrism and race. How can Australian authors from the second half of the $20^{\text {th }}$ century make sense of the contradictory mapping of global and local space? How do they apprehend the geography of a continent which resulted from the meeting of cultural plates below the crust of national sovereignty? How do they make sense of the mapping of global and local space under the historic scope of domination and colonization? This paper will examine the changes in the perception of the land and cultural identity that arise with the awareness that Australia is no longer an Anglo-Celtic centre but a multicultural nation in the Asia-Pacific with, at its heart, a vibrant Indigenous culture. It will endeavour to examine how Indigenous and non-Indigenous Australians can bridge the differences in their perception of the land and of belonging, acknowledging the increasingly multi-centred and inter-cultural character of Australian culture.

When Patrick White won the Nobel Prize in 1973, the Swedish Academy praised his epic and psychological narratives and insisted that White had introduced a new continent to literature. White's writing marked the formation of an Australian literary canon, a canon defined by European standards which implies an "otherness" of the works it excludes, and an authority of the works it includes. In fact, the ancient tales of the Indigenous tribes criss-crossing the Australian continent and designing the Dreaming $^{2}$ were simply ignored while the literary production stemming from the nationalist movement of the late $19^{\text {th }}$ century, with its attempt to define "Australia" and "Australianness," seemed to justify White's canonization as well as the idea that Australian writing had moved from the marginal space of popular culture to the central place of a canonical literature recognized by the academia.

However, Patrick White's claim that Australia was occupied by a great emptiness, in contrast with the "cult of forgetfulness" practised by white Australians regarding the fate of Aboriginal culture, underscored the need for white Australians to embrace the spiritual environment. White's stories debunked a whole discourse which had been largely mythical, somewhat racist, and which illustrated the insecurity of the AngloAustralians along with their strategy to produce a strong, self-confident national image. White's writing was hailed as high culture in a country that suffered a culturalcringe $^{3}$ while White, the author, wished to show that Australian fiction was not, as he claimed in his famous essay "The Prodigal Son" (1958), "the dreary, dun-coloured

2. The Dreaming is a state between waking and deep sleep, during which the individual receives messages from the ancestral beings. It is bound to the Dreamtime, which refers to the spiritual dimension of Indigenous existence, linking the present to the time of creation by spiritual forces in the here-and-now as well as to a time when ancestral beings emerged from beneath the earth and formed the landscape.

3. After World War II, the term "cultural cringe" was coined by A. A. Phillips in reference to the difficulties Australian artists and intellectuals faced in Australia. Phillips argued that Australians were prejudiced against the homegrown products, and deliberately overlooked them in favour of imported products, from Britain and the United States. 
offspring of Australian journalism” (39). As a strong anti-royalist he endeavoured to construct a body of fiction that was not looking back at Britain and reminiscing about the distant European paradise but rather shifting back to the core of reality. He used the Australian landscape as an icon for identity and a disruptive force against the European worldview.

A Fringe of Leaves (1976) is an allegory of colonial Australia, rewriting the real story of Eliza Fraser who travelled from England to Australia in 1836, was shipwrecked on a reef off the Queensland coast and spent six months, totally naked, with the Aboriginal tribe that saved her. Against a background of industrial development and social change, the novel's ethnological approach rests upon successive shifts and the hardships of the journey from rural Victorian England to the Australian inferno, convictism, the settler-society and the emerging mercantile economy, and the ambiguous and ominous encounter with an Aboriginal tribe. When Ellen Roxburgh, namely Eliza Fraser, is stranded in Tasmania (rather than Queensland as in the original story), the island-state and former penal-settlement, she becomes captive to another form of authority, the power of the colonized rather than of the colonizer. Ellen is, in fact, compelled to go native and endures an inevitable culture shock in the Australian outback - a veritable heart of darkness to her: "Her actual blackened skin, her nakedness beyond the fringe of leaves, were of no help to her; she was again white and useless, a civilized lady standing surrounded by this tribe of scornful blacks" (236). The character's experience verges on the surreal while the natural setting emphasizes the personal alienation of the non-Indigenous in the Antipodes. The desert surfaces as the place of the subjective experience of the unreality of the outside and colonial world rather than as a spiritual source of identity: "Her ghost drifted with the wraiths of mist, among the ghosts of trees, and found itself again haunting the shore, a bland, unobstructed verge which presented no sure way to escape to a lost soul, a woman, or a rational being" (228).

In displacing imagination from the margins (the cities and coastal places) to the interior, White opened up a space for the discourse of otherness and cross-cultural issues. But by locating identity in a geographically conceived world, he maintained a hierarchy of spaces, between a metropolitan centre and a marginal uncanny, sustaining a binary and Western perception of otherness. Mental exploration encroaches upon physical space, the desert and wilderness, while the act of writing not only subverts imperial identity and expansion but also re-creates landscapes and the land as a spiritual nexus, in reaction to decades of city materialism, cultural shallowness and colonial perceptions. Yet, White's probe of the mystical and psychological marked a new direction in Australian fiction in that it broke up Britishness, forcing it to move to the centre and collide with the Dead Heart. White's concern for what can be termed "the landscape of the mind," while it did not really interact with Indigenous culture, paved the way for an ecological impetus. The Australian outback generates mixed responses: it harks back to the settler perception that Australia achieved nationhood in the form of an imagined community, with a common future tied but distinct from Britain, but it also designates a new destiny manifested in the recognition of Indigenous Australia (Wright 30).

The desire to connect with indigenous appreciation of the land by partially melting Indigenous and non-Indigenous perceptions marks Judith Wright's poetry and essays. 
Her writing openly calls for a fusion between the Australian landscape and personal history. The post-colonial situation of Australia and decentred position of Australians are both perceived as an inability to connect entirely out of a fear inherited from the past and as a result of the collision between two cultures. The poet's vision seems to suggest that the settler-society conceived a marginal macrocosm - which serves as ground for identity - while the bush and untamed landscape creates pressure, forcing the colonized parts to collide and separate:

Australia is still, for us, not a country but a state - or states - of minds. We do not yet speak from within her, but from the outside: from the state of mind that describes, rather than expresses, its surroundings, or from the state of mind that imposes itself upon, rather than live through, landscape and event [...]. We are caught in the old nineteenth-century split of consciousness, the stunned shock of those who cross the seas and find themselves, as the Australian ballad puts it, in a "hut that's upside down." ("The Upside-Down Hut" 30)

Judith Wright's sense of belonging initiated a review of the colonial paradigm resting upon the pastoral land system by advocating a connection with the spiritual land and the embracing of the Australian environment as an oikos, a home rather than the outpost of the Empire, through a capacity to recognize the full drama of colonization and the Indigenous presence. The violence of colonial possession is addressed by celebrating the land as a collective site of memory, and as a means to escape from or alleviate the rhetoric of fear of and violence towards the cultural other - as a protection from an unfair white Australian perspective that discards rather than unites.

In a poem entitled "Space Between," alienation from the land means crisis of the language and indicates that the experience of colonialism generates a dislocation between the environment and the imported language used to describe it, that the tangible gap between the experienced place and language is part of the experience of the post-colonial subject, the very essence of displacement:

What is the space between,
enclosing us in one
united person, yet
dividing each alone.
Frail bridges cross from eye
to eye, from flesh to flesh,
from word to word: the net
is gapped at every mesh,
and this each human knows:
however close our touch
or intimate our speech,
silences, spaces reach
most deep, and will not close.
("Space Between," Alive 21)

Wright, who became a canonical figure in the field of nature writing and environmental activism, devises an ecological discourse and constructs a dialogical relation between secrecy and disclosure. Her concern for Indigenous rights is marked by a close relationship with poet Oodgeroo Noonuccal (aka Kath Walker), the first Indigenous Australian to be published in 1964, but also by a desire to tackle race relations at a time when the nation was oscillating between two worlds, the 
consumerist fate encouraged by political governance and the humanist destiny stemming from literary circles:

You were one of the dark children

I wasn't allowed to play with -

riverbank campers, the wrong colour,

(I couldn't turn you white)

("Two Dreamtimes," Alive 22)

Judith Wright's attempt to amalgamate divergent cultures and approaches suggests relocation of culture through hybridization, which "makes the process of cultural translation a complex form of signification" (Bhabha 172).

The search for connectedness and reconciliation with otherness stimulates hybrid forms as much as it displaces imperial history in an attempt to relocate Australia's indigenous reality. In The Road to Botany Bay (1987), Paul Carter examines the settlement of Australia as spatial history, insisting that spatial history not only returns to the root of things, grounding itself in origins and epistemologies, but that it also challenges long-established historical methodologies, offering alternative interpretations of the relationships between space, time, colonization and historical events. Carter's view that the post-colonial condition stems from dislocation, coincidence and pluralism forms the basis of much Australian fiction published from the 1970s onward - a fiction marked by a critique of nationalist discourse, racial exclusion and gender subordination at a time when issues ranging from land rights, migration and Australia's place in the Asia-Pacific region were debated in the postimperial nation.

In his play No Sugar, first performed in 1985, Indigenous playwright Jack Davis puts his own history on stage by tackling the brutality of the Moore River Settlement, a mission in Western Australia where many of the Aboriginal and mixed-race children were sent against their will, as part of the Stolen Generations. Positioned at the end of a long line of oral story-tellers and at the beginning of a blossoming written tradition, Davis uses a socio-political approach through language that constructs an I-subject through culturally essentialist definitions of the Other that simultaneously devalue, idealize, exclude and incorporate, while the silent native is able to break loose and crack the veneer of the imperial society. The dialogical form subverts the normative nature of English resting upon Strine, that is Australian English, and Nyoonga, the Aboriginal language from the south-west of Western Australia, as a result of what Bakhtin calls hybridization. Thus, the simultaneous use of Strine and Nyoonga generates a creolized form, which suggests that there are not only two but three languages at work: English as the Lingua Franca, and Strine and Nyoonga as the signifiers of a post-colonial reality. Davis utilizes language as an element of power so that, as Homi Bhabha argues in The Location of Culture:

The "language" metaphor raises the question of cultural difference and incommensurability, not the consensual, ethnocentric notion of the pluralistic existence of cultural diversity. It represents the temporality of cultural meaning as "multiaccentual", "discursively rearticulated". It is a time of the cultural sign that unsettles the liberal ethic of tolerance and the pluralist framework of multiculturalism. Increasingly, the issue of cultural difference emerges at points of social crises [...]; identity is claimed either from a position of marginality or in an attempt at gaining the centre: in both senses, ex-centric. (177) 
When one of the main characters, Milly, asks: "what's the matter, you mindgit?" (37), she is using the same linguistic structure as an Anglo-Australian saying: "what's the matter, you sick?" The hybrid form, which is supported by notes and a glossary of Aboriginal terms in the published edition of the play, is exemplified when Aboriginals and non-Aboriginals share some words and referents but have a different understanding of them. Thus, when Frank Brown, the unemployed white farmer, refers to Jimmy's "home" (I.v), the Justice of Peace asks "His what?" enticing Brown to correct himself and replace the term "home" by "his camp at Government Well" (34). The word "Home" in colonial discourse means "where the white is," it is not used in relation to blacks, who use "Country" for the traditional land of each Indigenous language group or community.

In Davis's play, the Aborigine enters Australian history through the language of the colonizer while not giving up on Aboriginal language and culture. The title of the play, No Sugar, encapsulates various meanings: the idea that Indigenous Australians cannot afford the comforts of a "Home Sweet Home"; the idea that they do not wish to assimilate and surrender to colonial rule by accepting the "sugarbag" - meaning the colonialist's bribes and sweeteners; or simply that the Sugar Bag Dreaming, the ancestral story, cannot be experienced by colonialized and objectified Indigenes since they are gradually becoming acculturated subjects.

The dialogization of languages is a constant process and language is always changing so that each voice can be listened to from the perspective of the other, not only suggesting that language is vitally important in understanding Indigenous heritage, that history is an oral history, but also that hundreds of languages and dialects existed (although many are now extinct) and that language, as well as geographic location, is used to identify different groups. Concepts of "home," in No Sugar, run counter to Judith Wright's view of home as an oikos and rely on a global system of interactions and a dismantling of colonial practices. Davis openly moves cultural otherness centre-stage so that mainstream culture is destabilized:

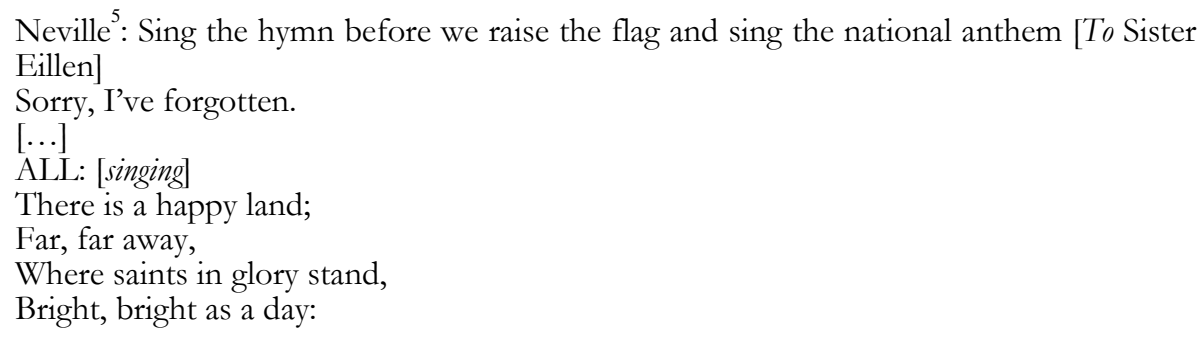

4. In the Dreamtime a man called Anwadi lived near the Mann River, about 150 miles from Oenpelli on the way to Maningrida in Central Arnhem Land. He became known as the "sugar bag man" because of his ability to find swarms of small black bees circling around dead branches, indicating the presence of wild honey. Once having located such a tree, he would cut down the dead branch with a stone axe, and scoop out the beeswax and sweet wild honey in the hive. He decided to travel throughout western Arnhem Land, teaching other people his skills, and eventually came to an area known as Marlgawo. lt was a land of rocky escarpments and plunging waterfalls, so he told his family they would all settle there. However two birds (wakwak) shouted out to Anwadi that the country belonged to them and they would not allow him to settle there. When Anwadi refused to move on, the birds hurled stone axes at him and his family, cutting off their legs. Anwadi retaliated by killing the birds with stones, and they turned to rock. The Sugar Bag people settled down happily, learning how to walk around without legs and continue to find wild honey. Eventually they all died and turned into trees or rocks, where their spirits live on forever.

5. A. O. Neville was the Chief Protector of Aborigines in Western Australia between 1915 and 1940. He took an active part in the removal of mixed-race children, the Stolen Generations. 
Oh, how they sweetly sing,

"Worthy is our Saviour King!"

Loud let His praises ring,

Praise, praise for aye!

[As the whites continue, the Aborigines break into full clear voice with a parody of the words.]

There is a happy land,

Far, far away.

No sugar in our tea,

Bread and butter we never see.

That's why we're gradually

Fading away.

(98, IV.v)

Jack Davis addresses cultural disruption and the reconnection of the Indigenous people with their spiritual country through what Edward Said codified as the voyage in, which encapsulates the movement and integration of marginal Otherness (the Third World) into the metropolitan First World. While Said suggested that the logos no longer dwells exclusively in London and Paris, Davis shows that Australian history no longer runs unilaterally, as Hegel believed, from east to west or from south to north, becoming more sophisticated and developed, less primitive and backward as it moves on. Rather, Davis argues that the weapons of criticism have become part of the historical legacy of Empire, in which the separations and exclusions of "divide and rule" are erased and surprising new configurations spring up (see Said 295).

Hybridity holds potential for change and belonging. It is often associated with a discourse on multiculturalism and cultural identity, to suggest that Australia is no longer the colony of the Empire and that indigenous history needs to be placed back at the centre of a broader national history. The search for home and claim for identity from a global perspective is at the heart of Dalwurra, a poem cycle by Mudrooroo Narogin (aka Colin Johnson). The publication of Mudrooroo's work, which was funded by the Australian Bicentennial Authority, ${ }^{6}$ occurred at a time when the imperial legacy from Britain and the history of European migration to Australia were being challenged by the founding of a multicultural society. In Dalwurra, the black bittern, a migratory bird, circles through the world, leaving from Perth (Western Australia) to reach Asia - a continent Indigenous people appear to originate from - and Britain in Odyssean fashion, experiencing the journey to colonized and colonizing places before undertaking the final journey home to embrace indigeneity and a sense of belonging. Mudrooroo introduces spiritual and uncanny elements, through references to Indian and Thai mythology as well as to the Australian Indigenous Dreaming, as reminders that a condition of unsettledness is part of the settler and multicultural nation. Thus, the flight and migration of the black bittern design a psychic map which appears as an illustration in the preface to the book (11), and which reads like an indigenous painting so that Indigenous sacredness manifests itself in the public domain of the modern and post-colonial nation:

6. The Australian Bicentennial Authority (ABA) was set up in 1988 to encourage projects that emphasize the nation's cultural heritage. It ensured cooperation between all states and State Councils, between the federal and state governments, advocating a sense of unity and nationhood. 


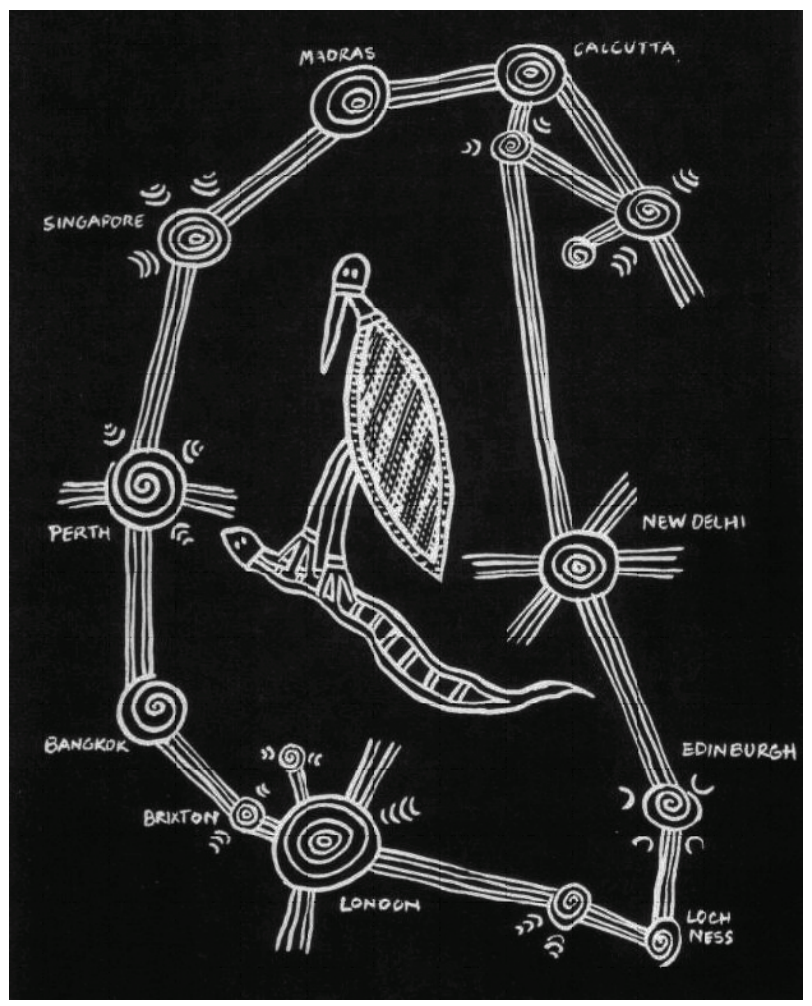

In his introduction to the poems, Mudrooroo indicates that Dalwurra shows "how Aboriginal song cycles may form the basis of inspiration for poems in English" and "of a continuing line of Australian expression," that "the vision of the poet changes from the mundanity of the everyday into the mythology of the eternal day" (9-10). Stylistic and generic experiments, along with narrative prose, interact to suggest multiple meanings and encode information as in the traditional manikay, ${ }^{7}$ implying a rhetorical process of cultural negotiation across a colonial divide rather than a mere binary opposition between colonizer and colonized. Thus, when he reaches home, the black bittern attempts to recover the lost Dreamtime by negotiating between an imposed whiteness and a perceptible blackness:

Wandering the beaches and creeks,

Wandering the beaches and creeks searching,

Searching for fish, searching the shoreline.

As one of a flock, as one of a flock,

Dalwurra rises to settle amidst the spinifex grass,

To settle among the bushes and rocks of his home -

Had there ever been a time of indigo-maroon?

7. In north-eastern Arnhem Land, the Yolngu people have been singing manikay for ever. Manikay are clan song series, passed down through generations from the ancestral beings that originally shaped and named the Yolngu homelands. They are sacred ritual songs but they are also songs about the land, the fauna and flora, the people and spirits. 
And then his feet stamp out the log-coffin and sweet honey

Residing, residing in the time of indigo-maroon.

("Home" 65)

In this poem, the time of the hybrid "indigo-maroon" suggests a continuity whereby official history (i.e. indigo) is deconstructed to be incorporated into otherness (i.e. maroon), whereby the centre is deconsecrated and demystified by the intersecting of different continents and stories, locating the Black Bittern's Dreaming tracks in a liminal space, between traditional Indigenous culture and non-Indigenous (Western) culture.

At the time, in the late 1980s, the marginal position of Indigenous Australia within Australian society was reflected through an Indigenous and a non-Indigenous perspective in the arts. Authors were moving closer to the basic structure of society and the spirit of Patrick White by looking at Australia as a "black country with a white enclave," experience in the Australian Bush. A distinctive environment, the Bush becomes the site of cultural difference from the Imperial centre, the uncanny core of a new Australian perception. It is the organic structure which crystallizes cultural identity through the interaction of rigid and antagonistic components, black and white Australia. However, the Black Bittern's migrations through time and place shows that cultures, like tectonic plates, not only interact by moving toward one another through convergence and partial melting, or away from one another through divergence, but that they may also slide past each other, through a process which is similar to a geological transforming motion, and create a fracture-zone or an in-between space for hybrid discourse.

Following the bicentenary celebrations of the arrival of the First Fleet from Britain, a number of non-Indigenous Australians, among whom writers, have shown a renewed interest in the fauna and flora of the country. This often involves a journey to the centre of the continent to confront the Dead Heart and the Bush as a voyage in - a modern journey that leads to a collision with ancient Australia, and in the process, a migration and exile to the liminal space where the European and non-European spheres touch. Roslynn Haynes, in her study of the desert and its impact on Australian culture, argues that to a certain extent, the centre of Australia and the associated Indigenous culture attract white Australians as a result of a need to overcome their own Eurocentric limitations and embrace a different kind of cultural enrichment (22).

Haynes's observation is at the centre of Pat Jacobs's novel, going Inland (1998), which illustrates the pilgrimage to and exploration of the Bush by an Anglo-Australian couple, Tom and Zoe Drewe, addressing issues of identity and the nature of belonging when Australia was embroiled in the Wik debate. This famous debate (and then ruling ${ }^{9}$ ) divided those in favour of Indigenous rights and those who claimed they

8. This definition of Australia is Paul Keating's, Australia's Prime Minister between 1991 and 1996. Keating was instrumental in refocusing Australia's consciousness on a different set of realities - namely Indigenous people and land rights, and the proximity with Asia and the need to separate from Britain. This view relocated Australia on its original cultural map and paved the way for a post-colonial nation.

9. The Wik decision refers to the High Court judgement in Wik Peoples v. State of Queensland (1996) which found native title to the Wik peoples' traditional lands had continued to exist despite pastoral leases in the area. While the opposing view argued that the effects of pastoral leases nullified native title, the judges ruled that native title and 
had a right to the land through (colonial) inheritance, re-enacting colonial denial of otherness and simultaneously bridging cultures.

going Inland explores the darkness of the Australian psyche, debunking identity and showing the extent to which Indigenous perception and occupation of space are overlapping, if not colliding with non-Indigenous appropriation of the land. Past and present are connected by the power responsible for the characters' estrangement and testify to colonial mapping, to geographical violence and acculturation of place: "The world around her [Zoe] seemed flat and without definition. The shallow hold Europe had on the continent, the lichen growth of foreign place names that covered the surface, was a temporary usurpation" (92). Zoe's impression accounts for the hidden discourse of maps, for the colonial cartographic representation of whiteness and the ensuing annihilation of blackness.

By heading north, where the Dreamtime is most visible, Zoe and Tom are confronted with the emptiness and silence of the interior, a silence that is in fact replete with the cries and claims erupting from the Indigenous haunting presence, the land bearing testimony to past injustices and cultural denigration. The Indigenous Dreamtime breaks through the characters' journey to uncover the history of the European migrants to Australia, and rather than simply writing back to British colonization and settlement, undermines the characters' values and causes failures within the colonial structure: "Time was the illusion. They did not move through it but within it. They lived on an island, captive and confined to what they had made of it. [...] The country was so hard. It worked on you, stripping away" (189). The Dead Heart surfaces as the force disrupting the characters' perception of their own identity. It releases the spiritual energy of the Dreamtime as much as it generates a rupture of national identity so that both Zoe and Tom realize that colonial claiming and demarcating of the land through the consciousness of forming a community, of sharing a common culture and destiny, which imposes language, religion and social mores, are responsible for their own sense of displacement. Their inherited imperial world is crumbling down and sliding under the strain of cultural shock, owing to an interaction with a neighbouring cultural otherness:

Zoe's skin prickled. Here was where the life was. Down here. Close to the earth. Where the Rock and the earth joined. The space of the cave was dense with the memory of people, their voices, movements and vitality. The rubble and dust on the floor carried the traces. She touched the walls, knowing that in the logicality of history, men and women had touched there also, leaving, as she did, the invisible imprint of her presence. [...] Here was the cave where Tjati died, the man, the red lizard, She had tried to grasp the stories, to place them in her mind [...], trying to memorise the Tjukurrpa law which was the evidence of ownership, but the reality was overpowering. [...] There were two realities and she inhabited one of them. What she allowed as a possibility was this exposure of herself to what was in the air, the stone, the water; to what remained beyond reason. (161-2)

Personal history is analogous to and merges with the history of the physical earth, resulting in a major sense of loss for the imagined community of the nation. This also implies that there is no core, considering that Australian culture is a contrapuntal ensemble, an interaction of diverse individuals and groups, so that its identity is bound 
to be based on an array of opposites, negatives and oppositions. Like Zoe, Tom Drewe needs to journey back in time and space, only to realize that the imperial component of the past cannot be separated from present realities and that he will, like Zoe, always be inhabited by a feeling of dislocation - which Margaret Atwood would call "the feeling of being alien, of being shut out, and the overwhelming wish to be let in” (72). Ghosts from Tom's family past emerge and compel him to drive back to the point of origin, the Western Australian Goldfields, where his Polish grandfather arrived in the late 19th century and stole the identity of a deceased Englishman, becoming a double mimic - a mimic of himself trying not to be a migrant Pole and a mimic of himself trying hard to be an Englishman - so that identity is conceived as a vector for annihilation, emptiness and loss: “'Zoe - I have to go.' How could he tell her: that he had to find a starting point? That, like the map, his interior was empty - a blank" (187).

Like most Australian authors concerned with land issues and who use the landscape as a central protagonist, Pat Jacobs conceptualizes the centre and the horizon as shifting entities, while the desert operates as the most potent symbol for the advocacy of "a convergence of Indigenous and non-Indigenous understanding, a collective spiritual consciousness that will be the true form of reconciliation" (Malouf 39-40). Non-Indigenous narrative trajectories emerge that write back to a centre, which is no longer the imperial centre but an active Indigenous centre. Other nonIndigenous authors like Richard Flanagan, Kate Grenville, Andrew McGahan and Tim Winton endeavoured to write about colonization in an attempt to redefine what "Australian" means in post-Mabo years, ${ }^{10}$ in the run-up to the apology to the Stolen Generations and at a time when migration issues, relationships with Asia and the growing influence of the US had become central. ${ }^{11}$ Their work reflects the agony of not belonging as an Anglo-Australian, the emergence of the multicultural ideal and the distortion of Australian values such as tolerance and egalitarianism. Winton's Dirt Music, McGahan's The White Earth, Grenville's The Secret River and Flanagan's Gould's Book of Fish, which were published around the same time, between 2001 and 2005, expose colonial history from different perspectives, whether regional, historical or political, only to chart a post-colonial Australia which is no longer an extension of the British or European centre but an independent and culturally distinctive nation in the Asia-Pacific area. These authors not only strike back against their country's rampant conservatism, especially during the political terms of liberal Prime Minister John Howard, but also suggest that Australia is multi-centred and that Indigeneity is one of its centres. They bring to the fore the pains of (not)belonging and the idea that nonIndigenous Australians have become exiles from within, in an Australia whose colonial foundations are shaken by Indigenous claims for land and cultural

10. Mabo refers to Eddie Mabo's action for land rights, to the Mabo judgement and ruling by the High Court of Australia in 1992. The Mabo litigation overturned the accepted doctrine of Terra Nullius in favour of the common law doctrine of Aboriginal title.

11. Since 9/11, Australian society has been affected by the War on Terror, the terrorist attacks in Indonesia and the impact of Bush's neo-conservative discourse on the Liberal-National Party coalition government. By steering further to the right and towards US imperialistic designs, Australia has been initiating what looks like a return to colonial dependency and mimicry. John Howard, Australia's PM from 1996 to 2007, strived to maintain an AngloAustralian identity and a denial of cultural otherness, moulding Australia as a distinctive continent in the Asia-Pacific region. 
recognition. In fact, they correlate with the idea raised by Australian historian Manning Clark that "white people are condemned to live in a country where they have no ancestral spirits" since the "conqueror has become the eternal outsider, the eternal alien" and that white Australians must "either become assimilated or live the empty life of a people exiled from their spiritual strength" (qtd. in Reid 13). Such a claim is addressed to the post-settler society and the Anglo-Australian mainstream, bringing to the fore sensitive issues such as the impossibility of ever appropriating or being absorbed spiritually into Aboriginality, an impossibility that Tim Winton, for instance, makes clear when asked about his use of landscape as writing material and a possible interest in Indigeneity:

I would say that I was closer to Aboriginality than my Scottish ancestors were here, but that's still not saying much. I have learnt to be closer to the land, but this hardly compares to genuine Aboriginal belonging. I wouldn't make too bold a claim for myself here. I envy Aborigines for their oneness with the land and the spirit of the country but I don't envy them their confusion and irredeemable loss. (qtd. in Ben-Messahel 13)

Winton's stance surfaces in Dirt Music, a novel which was published in 2001, during the celebrations for the centenary of Australia's Federation. The story interweaves Indigenous and non-Indigenous sensibilities so that the non-Indigenous character becomes an Aborigine, namely the individual who has been there from the beginning, while the Indigenous remains the first inhabitant of the country, despite an inevitable hybridization which can be seen through the assimilated and lost mixedraced Indigenous (Dirt Music 303). Winton's novel (like his writing in general) juxtaposes and negotiates individual and cultural differences in a Bakhtinian sense so that the dialogization of languages happens within the boundaries of a single dialect, establishing links that transcend cultural divides, and "rejoin experience and culture," to take up an idea expressed by Edward Said in Culture and Imperialism:

To rejoin experience and culture is [...] to read texts from the metropolitan centre and from the peripheries contrapuntally, according neither the privilege of "objectivity" to "our side" nor the encumbrance of "subjectivity" to "theirs". The question is a matter of knowing how to read [...], and not detaching this from the issue of knowing what to read. Texts are not finished objects. They are, as [Eric] Williams once said, notations and cultural practices. And texts create not only their own precedents, as Borges said of Kafka, but their successors. (312-3)

Famous for his depiction and use of the Western Australian coastline, ${ }^{12}$ a place where most Anglo-Australians and Australians of European descent settled, having come from the ocean, ${ }^{13}$ Winton writes from a marginal space, a wild environment which is viewed as a vibrating component of Australian culture. His stories indicate that the balance of power between the local/national and the imported/global is

12. Tim Winton's most recently published novel, Breath (2008), is set on the coast and makes the ocean and the water-element major influences in the characters' lives. The ocean is a force which takes precedence over the earth and the unstable or shabby reality of marginal individuals.

13. The ocean was the principal medium of communication between distant coastal places and bearer of the history of the first fleet sailing to Sydney Cove in 1788. It enabled the West to unify inhabited and habitable worlds, including the Americas. The population distribution map shows that Australians tend to settle along the coast - on the margins - rather than in the interior. 
shifting and uneven, and that this shift encourages distinctive local cultures, and in the process stimulates a regional impetus. ${ }^{14}$

Australia's post-colonial situation and its ability to become a republic, from the end of the $20^{\text {th }}$ century, opened up the possibility of a dialogical rhetoric that views all human activity and all human discourse as a complex unity of differences, so that resistance to imperial hegemony triggers a post-colonial transformation whereby Australian fiction appropriates dominant discourses imported from England, remodels and uses them for its own self-empowerment at a time when Australian geopolitics are drifting towards Asia. In his book Is Australia an Asian Country? (1997), Stephen Fitzgerald insists that new community relations are being created within Asia and that Australia should actively be part of it by seeking Asian recognition and integration in the region. Fitzgerald argues that Anglo-Australia should become a part of Asia - and remove itself from under the influence of the Western centres, Europe and North America - to embrace Asian values and perceptions (14). Such claims, even though still scarce in the national consciousness, posit a transition from Britishness and subsequent Americanization - to an Asianness that would not only be economic but also culturally significant.

Global political instabilities have not only affected the ways in which the world is viewed and conceived but have also sparked disunity, while a wish for national unity persists - a phenomenon that has become all the more perceptible, in Australia, with the influx of new migrants and refugees, especially from the Middle-East, since the first Gulf War. Novelist and human rights activist Eva Sallis, in her first novel titled Hiam (1998), wonders about the ways in which one represents and defines another culture. An intercultural understanding relies on the ability to reflect upon and explore cultural difference in a meaningful way, to subvert the hegemony of Western discourse. Migrant aesthetics and experience are explored by tracing the exile of a female Muslim migrant, Hiam, in the Australian outback as grievance for her lost ones. The character is depicted as the "new" Arab migrant to Australia who, contrary to common view, is educated, is able to fend for herself and escape from male domination, but yet is depicted as an eternal outcast. Born a Yemeni, brought up as a Lebanese and having become a Palestinian through marriage, Hiam belongs nowhere in the vast emptiness of a multicultural background.

Sallis explores the post-colonial condition through the collision between the old Western world and a new "oriental" one to uncover contemporary Australia's increasingly complex fate. She resorts to the classic form of the quest to combine it with the tradition of Arabic story-telling exemplified in The Arabian Nights, weaving an emotional and spiritual tale in a multicultural nation where "Islam is a curious word" (20). Hiam's fragmented memories are combined with a fleeting present and the confrontation with the Australian landscape, with (again) a perceptible Indigenous Dreamtime: "She was on the endless road, stretching to infinity ahead and behind. [...] Before and After are places, knots on a string, roadside shrubs. Now is infinitesimally different in its grasses, rocks, bones and dust from, say - now" (54-5). The isolated places and the desert are either reminders of things or people from the distant home, with Indigenous characters who often appear to resemble one's 
otherness (Hiam mistaking Noah, the Indigene, for a Sudanese [128]), while urban Australia encapsulates the character's loss and emptiness, the death of a husband and the Anglo-Australianization of a cherished daughter. Stories converge and interact so that the position of the migrant and Middle-Eastern Other surfaces on the cultural topography of Australia. Hiam's past and memories are fleeting layers narrated in the present tense while her current story is told in the past. Reality is delineated through a fragmented narrative that subverts the scope of time and place:

She went eagerly back to the car and sat in it. She felt relieved but very far from home.

She couldn't think of anyone she knew having even mentioned Port Augusta.

Hiam and Masoud stand looking into their house within the scarred and pockmarked yard yawning dimly in the falling darkness behind them. (10)

In Hiam Eva Sallis endeavours to sketch a postmodern and post-colonial image of Australia, interweaving local, national and imported traditions, suggesting a mobility of the global into the local and, as a number of Australian writers advocate nowadays, an extension of the canon, a canon inherited from Patrick White and reconfigured over time to map the evolution of Australian writing. Australia emerges simultaneously as a new and ancient culture, distant from Europe and from the Middle-East, still enmeshed in an imperial structure but drifting towards diversity and otherness. Thus, White's literary canonization has generated strong stresses on Australian culture and, owing to White's deconstructive approach and social commitment, has encouraged generations of Australian writers to contribute to the enrichment of the literary landscape. For the writers, concepts of "home" no longer rest upon the reference to Albion as the point of origin but rather emerge from a cultural interchange between the local and the global, while the Indigenous claim for land rights and sacredness is, as Ken Gelder and Jan Jacobs rightly argue, "always conflictual, leading as much to restriction as it can to activation" (xvi). In their respective examination of the AngloAustralian mainstream, such writers seem to suggest that not only are AngloAustralians exiles in their own country but that Australia, as David Carter suggests in the introduction to Dispossession, Dreams, Diversity, could be said to have been born global considering that it has been shaped by its regional location and global relations. These writers, Indigenous and non-Indigenous, posit the idea that there is, in fact, no "core" in Australia, but a vast territory with many geographies and countries - literary tectonic plates triggering a never-ending process of assembly, breakup, dispersal and reassembly, so that land and text operate as a dynamic to reconfigure cultural diversity and belonging

Salhia BEN-MESSAHEL, Université Charles-de-Gaulle - Lille 3

\section{Works Cited}

ATwOOD, Margaret. Strange Things: The Malevolent North in Canadian Literature. London: Virago, 2004. BHABHA, Homi K. The Location of Culture. 1994. London: Routledge, 1998.

Ben-Messahel, Salhia. Mind The Country: Tim Winton's Fiction. Nedlands, WA: U of Western Australia P, 2006.

BenneTt, Bruce. The Oxford Companion to Australian History. Melbourne: Oxford UP, 1998.

CARTER, David. Dispossession, Dreams and Diversity. Frenchs Forest, NSW: Pearson Longman, 2006.

CARTER, Paul. The Road to Botany Bay. London: Faber, 1987. 
DAVIS, Jack. No Sugar. Sydney: Currency, 1986.

FitzGerald, Stephen. “Is Australia an Asian Country?" St. Leonards, NSW: Allen \& Unwin, 1997.

FlanNagan, Richard. Gould's Book of Fish. Sydney: Pan Macmillan, 2001.

GELDER, Ken, and Jane JACOBS. Uncanny Australia. Carlton South: Melbourne UP, 1998.

Grenville, Kate. The Secret River. Melbourne: Text Publishing, 2005.

HAYNES, Roslynn. Seeking the Centre. Cambridge: Cambridge UP, 1998.

JACOBS, Pat. going Inland. South Fremantle: Fremantle Arts Centre Press, 1998.

MAlOUF, David. A Spirit of Play: The Making of the Australian Consciousness. Sydney: ABC, 1998.

MCGAHAN, Andrew. The White Earth. Sydney: Allen \& Unwin, 2004.

NARogin, Mudrooroo [Colin Johnson]. Dalwurra. Nedlands, WA: U of Western Australia, 1988.

PHILlips, Arthur. "The Cultural Cringe." The Australian Tradition: Studies in a Colonial Culture. Melbourne: Cheshire, 1958.

READ, Peter. Belonging: Australians, Place and Aboriginal Ownership. Cambridge: Cambridge UP, 2000.

SAID, Edward. Culture and Imperialism. London: Vintage, 1994.

WhiTe, Patrick. "The Prodical Son." Australian Letters 1.3 (1958). Repr. in The Oxford Anthology of Australian Literature. Ed. Leonie Kramer and Adrian Mitchell. Melbourne: Oxford UP, 1985. n. p.

- A Fringe of Leaves. Harmondsworth, Middlesex: Penguin, 1976.

WinTON, Tim. Dirt Music. Sydney: Macmillan, 2001.

Wright, Judith. “The Upside-Down Hut.” Australian Letters 3.4 (1961): n. p.

—. Alive. Poems: 1971-72. Sydney: Angus \& Robertson, 1973. 